\title{
Pengaruh Gaya Kepemimpinan Terhadap Kinerja Dosen dan Pegawai STIKes Muhammadiyah Lamongan
}

\author{
Abdul Majid ${ }^{1}$
}

\begin{abstract}
ABSTRAK
Kinerja pegawai di STIKES Muhammadiyah semakin menurun, dengan masalah tersebut peneliti ingin 1) mengetahui gaya kepemimpinan yang diterapkan oleh STIKes Muhammadiyah Lamongan dan 2) untuk mengetahui pengaruh positif gaya kepemimpinan pada kinerja pegawai. Jenis penelitian ini yaitu kuantitatif, Populasi dalam penelitian ini adalah 83 pegawai bagian administrasi dan dosen STIKes Muhammadiyah Lamongan. Jumlah sampel yang digunakan 74 responden. Teknik pengambilan sampel yang digunakan adalah teknik simple random sampling. Teknik pengumpulan data yang digunakan adalah kuesioner yang telah di uji validitas dan reliabilitas. Teknik analisis data menggunakan analisis regresi linear sederhana. Hasil penelitian menunjukkan bahwa 1) gaya kepemimpinan yang digunakan pada STIKes Muhammadiyah Lamongan adalah gaya kepemimpinan demokratis dan 2) gaya kepemimpinan berpengaruh positif terhadap kinerja Pegawai pada STIKes Muhammadiyah Lamongan.
\end{abstract}

Kata Kunci: gaya kepemimpinan, kinerja pegawai

\section{PENDAHULUAN}

Kata kepemimpinan biasanya sangat berhubungan erat dengan manajer. Seorang manajer biasanya disebut dengan pemimpin yang dapat mengelola sumber daya manusia yang ada dalam perusahaan. Namun dalam menjalankan suatu kegiatan dalam organisasi tentu saja tidak mudah, karena pada saat menjalankannya tentu saja akan mengalami rintangan maupun hambatan. Salah satu rintangan atau hambatan yang terjadi adalah kinerja sumber daya manusia yang tidak baik. Hal ini biasanya di sebabkan oleh hubungan antara pimpinan dengan pegawai yang menyebabkan ketidak senangan pegawai maupun kesenangan pegawai terhadap pekerjaan pada perusahaan/organisasi.

Salah sasaran pengelolahan sumber daya manusia pada fungsi manajemen organisasi berkaitan dengan masalah kepemimpinan. Seseorang yang telah ditunjuk sebagai pemimpin untuk memimpin bawahannya, dialah yang harus menjalankan fungsi organisasi itu sendiri yang menentukan atas berhasil tidaknya suatu perusahaan. Kepemimpinan yang sukses menunjukkan bahwa pengelolaan suatu organisasi atau perusahaan berhasil dilaksanakan dengan sukses juga.
1. Sekolah Tinggi llmu Kesehatan Muhammadiyah Lamongan, Jalan Raya Plalangan Plosowahyu, Km.3, Wahyu, Plosowahyu, Kec. Lamongan, Kabupaten Lamongan, Jawa Timur 62218 Indonesia

EMail

majidstiekhad@gmail.com

Submitted Juli 2019 Accepted: Juli 2019

JAS-PT

JURNAL ANALISIS SISTEM PENDIDIKAN TINGGI ISSN 2580 - 5339 eISSN $2620-5718$

Volume 3

Nomor 1

JULI 2019

Hal $21-30$

FORUM DOSEN INDONESIA 
Setiap kemampuan dalam kepemimpinan harus melekat erat pada diri seorang pemimpin, apapun tanggung jawab yang harus diterimanya. Karena tanpa adanya kemampuan memimpin terlebih dalam hal mengelola sumber daya manusia, tidak memungkinkan seorang pemimpin berhasil dengan baik dalam melaksanakan tanggung jawabnya. Menurut Sjafri dan Aida (2007 : 137) seorang manajer perlu memiliki kemampuan mengelola pegawai secara efektif, keterampilan manajemen, dan kemampuan memimpin.

Selain itu, manajer harus memahami dan menyadari bahwa tantangan terpenting yang dihadapi adalah bagaimana menerapkan ketiga aspek tersebut secara tepat dalam situasi tertentu untuk mencapai hasil optimum berupa mutu sumber daya manusia yang memuaskan. Sikap dan gaya prilaku pemimpin sangat besar pengaruhnya terhadap organisasi yang dipimpinnya, hal ini dapat berpengaruh terhadap produktivitas organisasi. Setiap pemimpin pada dasarnya memiliki prilaku yang berbeda-beda dalam memimpin para bawahannya hal ini diartikan oleh bawahannya sebagai gaya kepemimpinan.

Gaya kepemimpinan merupakan suatu cara pimpinan untuk mempengaruhi bawahannya yang dinyatakan dalam bentuk pola tingkah laku atau kepribadian. Seorang pemimpin harus memiliki suatu program dan berprilaku secara bersama-sama dengan para pegawainya untuk menggunakan cara atau gaya kepemimpinan tertentu, sehingga kepemimpinan mempunyai peranan yang sangat penting sebagai kekuatan dinamika yang mendorong, memotivasi, dan mengkoordinasikan para pegawai dalam mencapai tujuan.

Salah satu sasaran penting dalam rangka manajemen sumber daya manusia dalam suatu perusahaan adalah terciptanya kepuasan kerja setiap anggota pegawai yang bersangkutan yang lebih lanjut akan meningkatkan prestasi kerjanya. Sjafri dan Aida (2007 : 153) tiap manajemen perlu mengelola dan mengetahui kinerja pegawainya, apakah sudah sesuai dengan standar kinerja perusahaan atau tidak. Dengan mengetahui kinerja perusahaan maka akan lebih mudah untuk mengetahui seberapa efektif dan berhasilnya pengembangan pegawai. Dengan demikian, dapat diketahui faktor-faktor apa yang mempengaruhi kinerja baik ditinjau dari sisi intrinsik maupun ekstrinsik pegawai.

Selain itu kinerja dapat diartikan sebagai ukuran keberhasilan dari pegawai. Kinerja dikonsepsikan sebagai prilaku seseorang dalam menetepkan sasaran kerja, pencapaian terget sasaran kerja, cara kerja dan sikap pribadi seseorang. Tercapainya tujuan organisasi hanya dimungkinkan karena upaya para pelaku yang terdapat dalam organisasi untuk berkinerja dengan baik. Seorang pegawai yang memiliki kinerja yang tinggi dan baik dapat menunjang tercapainya tujuan dan sasaran yang telah ditetapkan oleh perusahaan. Untuk dapat memiliki kinerja yang tinggi dan baik, seorang pegawai dalam melaksanakan pekerjaannya harus memiliki keahlian dan ketrampilan yang sesuai dengan pekerjaan yang ditekuninya. Namun kadangkala pimpinan kerap kali memerintah para pegawainya dengan sesuka hati tanpa memperhatikan kondisi pegawai tersebut. Sehingga hal tersebut akan berdampak pada kinerja pegawai yang

JAS-PT

JURNAL ANALISIS SISTEM PENDIDIKAN TINGG

ISSN $2580-5339$

eISSN $2620-5718$

Volume 3

Nomor 1

JULI 2019

Hal $21-30$

FORUM DOSEN INDONESIA

\section{kurang baik.}

Ketidak mampuan pegawai menjalankan tugasnya sesuai dengan tanggung jawab mereka bukan disebabkan karena pegawai tersebut tidak mampu mengerjakan tugas tersebut dengan baik. Namun hal ini dapat terjadi karena pegawai tersebut tidak bisa menyesuaikan gaya kepemimpinan para pemimpinnya sendiri sehingga pegawai tersebut merasa kurang dihargai oleh pimpinan yang ada diperusahaan atau organisasi. Apabila kinerja pegawai kurang baik maka hal tersebut akan berdampak 
pada tugas- tugas yang harus dikerjakan oleh pegawai yang sudah menjadi tanggung jawab mereka. Oleh karena itu, seorang pemimpin harus mengubah gaya kepemimpinan yang dapat memberikan kenyamanan bagi pegawai yang bekerja di dalam suatu perusahaan.

Dengan mengubah gaya kepemimpinan yang dapat diterima pegawai, maka pegawai dapat menjalankan tugas dan tanggung jawab mereka dengan lebih baik lagi sehingga tujuan perusahaan dapat tercapai dengan maksimal. Gaya kepemimpinan dapat dikatakan baik jika gaya kepemimpinan tersebut dapat diterapkan oleh seorang pemimpin dengan baik dan dapat diterima oleh pegawai yang ada di perusahaan tersebut sehingga kinerja pegawai tersebut dapat ditingkatkan. Apabila kinerja pegawai dapat dijalankan dengan baik maka hal ini akan berdampak baik pada pencapaian tujuan perusahaan. Oleh karena itu gaya kepemimpinan sangat berperan penting dan perlu diperhatikan oleh seorang pemimpin. Dengan gaya kepemimpinan yang sesuai maka seorang pemimpin harus dapat berkomunikasi dengan baik dan dapat bekerja sama dalam hal tugas dan tanggung jawab.

Tujuan penelitian ini adalah 1) mengetahui gaya kepemimpinan yang diterapkan oleh STIKes Muhammadiyah Lamongan dan 2) untuk mengetahui pengaruh positif gaya kepemimpinan pada kinerja pegawai STIKes Muhammadiyah Lamongan

\section{TINJAUAN PUSTAKA}

Kepemimpinan menurut Amirullah (2015:167) adalah orang yang memiliki wewenang untuk memberi tugas, mempunyai kemampuan untuk membujuk atau mempengaruhi orang lain dengan melalui pola hubungan yang baik guna mencapai tujuan yang telah ditentukan.

Menurut Wirawan (2013 : 352) Teori-teori kepemimpinan paling banyak dibahas oleh para teoritis dan penelitian kepemimpinan adalah teori mengenai gaya kepemimpinan. Gaya kepemimpinan sangat penting karena gaya kepemimpinan mencerminkan apa yang dilakukan oleh pimpinan dalam mempengaruhi para pengikutnya untuk merealisasi misinya. Teori gaya kepemimpinan sering merupakan bagian dari teori kepemimpinan lainnya.

Teori-teori gaya kepemimpinan berdasarkan penelitian diantaranya adalah :

1. Teori Ohio State University

Teori ini berdasarkan pada dua dimensi:

a. Dimensi consideration (dimensi perhatian terhadap bawahan) adalah tinggi tendahnya pimpinan bertindak dan berprilaku dengan pola bersahabat dan mendukung, menunjukkan perhatian terhadap bawahannya dan memperhatikan kesejahteraan, indikator prilaku kepemimpinan dalam dimensi ini adalah: Membantu bawahan dalam menyelesaikan tugas; Menyediakan waktu untuk mendengarkan dan mendiskusikan masalah dan keluhan yang dihadapi bawahan; Menerima saran bawahan; Memperlakukan bawahan dengan cara yang sama; dan Memperhatikan kesejahteraan bawahan.

b. Dimensi initiating structure (Perhatian terhadap tugas) adalah tinggi rendahnya pimpinan mendefinisikan dan menstrukturasi dan menentukan peran bawahannya dalam mencapai tujuan yang telah ditetapkan. Indikator perilaku pemimpin dalam dimensi ini adalah: Mengkritik dan marah terhadap

JAS-PT

JURNAL ANALISIS SISTEM PENDIDIKAN TINGGI ISSN $2580-5339$ elSSN $2620-5718$

Volume 3

Nomor 1

JULI 2019

Hal $21-30$

FORUM DOSEN INDONESIA 
bawahannya yang malas dan berkinerja rendah; Memberikan tugas kepada bawahannya secara rinci; Mengingatkan bawahan untuk mengikuti prosedur standar kerja dan standar kinerja; Menentukan target keluaran;

2. Teori University of Michigan

a. Perilaku berorientasi pada ketugasan.

Para manajer yang efektif melakukan pekerjaan yang berbeda dengan para bawahannya. Mereka mengkonsentrasikan dirinya pada fungsi prilaku ketugasan seperti perencanaan, pensekedulan pekerjaan, mengoordinasi aktivitas bawahan, menyediakan sumber-sumber dan bantuan teknis yang diperlukan bawahan.

b. Perilaku berorientasi hubungan

Para manajer dengan gaya ini memusatkan perhatiannya pada hubungan antar manusia. Mereka sopan dan mendukung bawahannya dengan percaya diri serta berupaya memahami problem yang dihadapi bawahannya

Menurut (Robis 2006 : 260 dalam internet) indikator atau kriteria untuk mengukur kinerja pegawai secara individu ada lima indikator yaitu:

1. Kualitas. Kualitas kerja diukur dari persepsi pegawai terhadap kualitas pekerjaan yang dihasilkan serta kesempurnaan tugas terhadap keterampilan dan kemampuan pegawai.

2. Kuantitas. Kuantitas merupakan jumlah yang dihasilkan dan dinyatakan dalam istilah seperti jumlah unit, jumlah sirkulasi aktivitas yang diselesaikan.

3. Ketepatan waktu. Ketepatan waktu merupakan tingkat aktiviras diselesaikan pada waktu yang dinyatakan, dilihat dari sudut koordinasi dengan hasil output serta memaksimalkan waktu yang tersedia untuk aktivitas lain.

4. Efektifitas. Efektivitas merupakan tingkat penggunaan sumber daya organisasi dimaksimalkan dengan maksud menaikkan hasil dari setiap unit dalam menggunakan sumber daya.

5. Kemandirian. Kemandirian merupakan tingkat seorang pegawai yang nantinya akan dapat mnjalankan fungsi kerja pada komitmen kerjanya. Hal ini merupakan suatu tingkat dimana pegawai mempunyai komitmen kerja dengan insting dan tanggung jawab pegawai terhadap kantor

JAS-PT

JURNAL ANALISIS SISTEM PENDIDIKAN TINGG ISSN $2580-5339$ eISSN $2620-5718$

Volume 3

Nomor 1

JULI 2019

Hal $21-30$

\section{METODOLOGI PENELITIAN}

Jenis penelitian yang digunakan adalah kuantitatif, menurut Arikunto (2002:11), penelitian kuantitatif memiliki kejelasan unsur yang dirinci sejak awal, langkah penelitian yang sistematis menggunakan sampel yang hasil penelitiannya diberlakukan untuk populasi, memiliki hipotesis jika perlu, memiliki disain jelas dengan langkahlangkah penelitian dan hasil yang diharapkan, memerlukan pengumpulan data yang dapat mewakili serta ada analisis data yang dilakukan setelah semua data terkumpul.

Penelitian ini dilakukan di STIkes Muhammadiyah Lamongan, pengambilan data dilakukan pada Bulan Juni s/d Oktober 2018. Dengan jumlah sampel 74 orang pegawai STIKes Muhammadiyah Lamongan Instrumen data yang digunakan dalam penelitian ini meliputi uji validitas dan uji reliabilitas. Sedangkan analisis data dengan menggunakan deskriptif dan analisi regresi linier sederhana. 


\section{HASIL DAN PEMBAHASAN}

\section{Validitas dan Reliabilitas Variabel Gaya Kepemimpinan}

Hasil Uji validitas dan reliabitas terhadap pertanyaan pada variable Gaya kepemimpinan dapat dilihat pada tabel 1

Tabel 1 Analisis Validitas dan Reliabilitas Gaya Kepemimpinan

\begin{tabular}{ccccc}
\hline No & Kuesioner & $\mathrm{r}$ hitung & $\mathrm{r}$ table & Keterangan \\
\hline 1 & $\mathrm{q} 1$ & 0.227 & 0.531 & Valid \\
2 & $\mathrm{q} 2$ & 0.227 & 0.659 & Valid \\
3 & $\mathrm{q} 3$ & 0.227 & 0.755 & Valid \\
4 & $\mathrm{q} 4$ & 0.227 & 0.707 & Valid \\
5 & $\mathrm{q} 5$ & 0.227 & 0.744 & Valid \\
6 & $\mathrm{q} 6$ & 0.227 & 0.637 & Valid \\
7 & $\mathrm{q} 7$ & 0.227 & 0.630 & Valid \\
8 & $\mathrm{q} 8$ & 0.227 & 0.629 & Valid \\
\hline \multicolumn{5}{c}{ Reliability Statistics : Cronbach's Alpha } \\
\hline
\end{tabular}

\section{Sumber : Data primer diolah}

Tabel 1 tersebut di atas menunjukkan bahwa ke delapan butir pernyataan yang terdapat pada variabel Gaya Kepemimpinan, koefisien korelasi $>0.227$, dan nilai pada Cronbach's Alpha > 0.60. Dapat disumpulkan bahwa peryataan yang terdapat pada variable Gaya kepemimpinan sudah valid dan reliabel dan dapat memenuhi syarat pada uji validitas dan reliabilitas.

\section{Validitas dan Reliabilitas Variabel Kinerja Pegawai}

Hasil Uji validitas dan realibitas terhadap pertanyaan pada variable Kinerja pegawai dapat dilihat pada tabel 2 dibawah ini

Tabel 2 Analisis Validitas dan Reliabilitas Kinerja Pegawai

\begin{tabular}{|c|c|c|c|c|}
\hline No & Kuesioner & $r$ hitung & $r$ table & Keterangan \\
\hline 1 & $\mathrm{q} 1$ & 0.227 & 0.488 & Valid \\
\hline 2 & $\mathrm{q} 2$ & 0.227 & 0.778 & Valid \\
\hline 3 & $\mathrm{q} 3$ & 0.227 & 0.651 & Valid \\
\hline 4 & $\mathrm{q} 4$ & 0.227 & 0.516 & Valid \\
\hline 5 & $\mathrm{q} 5$ & 0.227 & 0.693 & Valid \\
\hline 6 & $\mathrm{q} 6$ & 0.227 & 0.781 & Valid \\
\hline 7 & $\mathrm{q} 7$ & 0.227 & 0.635 & Valid \\
\hline 8 & $\mathrm{q} 8$ & 0.227 & 0.793 & Valid \\
\hline \multicolumn{4}{|l}{} \\
\hline
\end{tabular}

\section{Sumber : Data primer diolah}

Tabel 2 tersebut diatas menunjukkan bahwa kedelapan butir pernyataan yang terdapat pada varibel Kinerja Pegawai, koefisien korelasi $>0.227$, dan nilai pada Cronbach's Alpha $>0.60$. Dapat disimpulkan bahwa pernyataan yang terdapat pada variable kinerja pegawai sudah valid dan reliabel dan dapat memenuhi syarat pada uji validitas dan reliabilitas.

\section{Analisis Tanggapan Responden Terhadap Setiap Pernyataan Pada Gaya Kepemimpinan}

Untuk mengetahui gaya kepemimpinan seperti apa yang diterapkan di STIKes Muhammadiyah Lamongan, maka ditampilkan hasil kuesioner gaya kepemimpinan atas hasil jawaban pada 60 responden dari 8 pernyataan. Dalam penelitian ini untuk mencari rata-rata dari setiap jawaban responden guna untuk memudahkan menilai dari

JAS-PT

JURNAL ANALISIS SISTEM PENDIDIKAN TINGGI ISSN $2580-5339$ eISSN $2620-5718$ Volume 3

Nomor 1 JULI 2019 Hal $21-30$

FORUM DOSEN INDONESIA 
rata-rata tersebut, maka dapat menggunakan interval untuk menentukan panjang kelas, dengan rumus sebagai berikut Sudjana (2001:79):

$$
p=\frac{\text { Rentang }}{\text { Banyak kelas }}
$$

Dimana

$P=$ Panjang kelas interval

$\mathrm{R}=$ Data terbesar - data terkecil

Banyaknya kelas $=5$

$p=\frac{5-1}{5}$

$p=0,8$

Maka interval dari kriteria penilaian rata-rata dapat diinterpretasikan sebagai berikut:

Tidak Demokratis : :1,00-1,79

Kurang Demokratis : $1,80-2,59$

Cukup Demokratis : $2,60-3,39$

Demokratis : : $3,40-4,19$

Sangat Demokratis : $4,20-5,00$

Tabel 3 Tanggapan Responden Mengenai Gaya Kepemimpinan STIKES Muhammadiyah Lamongan

\begin{tabular}{|c|c|c|c|c|c|c|c|}
\hline No & Peryataan & SS & $S$ & $\mathrm{~N}$ & TS & STS & Rata-rata \\
\hline 1 & Pernyataan 1 & 18 & 50 & 3 & 3 & & 4,12 \\
\hline 2 & Pernyataan 2 & 14 & 44 & 13 & 3 & & 3,05 \\
\hline 3 & Pernyataan 3 & 7 & 39 & 23 & 5 & & 3,64 \\
\hline 4 & Pernyataan 4 & 6 & 42 & 21 & 5 & & 3,66 \\
\hline 5 & Pernyataan 5 & 5 & 29 & 27 & 13 & & 3,35 \\
\hline 6 & Pernyataan 6 & 2 & 39 & 28 & 5 & & 3,51 \\
\hline 7 & Pernyataan 7 & 3 & 31 & 28 & 12 & & 3,33 \\
\hline 8 & Pernyataan 8 & 5 & 29 & 26 & 14 & & 3,33 \\
\hline & Total & & & & & & 27,99 \\
\hline & Rata Rata & & & & & & 3,49 \\
\hline
\end{tabular}

Sumber : Data primer diolah

Berdasarkan pada tabel 3, dapat diketahui tanggapan responden mengenai pernyataan gaya kepemimpinan pada STIKes Muhammadiyah Lamongan dapat dikatakan baik, Hal ini dapat dilihat dari pernyataan pada tabel di atas nilai terendah terdapat pada pernyataan 2 dengan nilai rata-rata 3,05 . Sedangkan nilai tertinggi terdapat pada pernyataan 1 dengan nilai rata-rata sama 4,12. Dengan demikian rata-rata keseluruhan dari 8 pernyataan yaitu 3,49 yang berada pada interval $3,40-4,19$, sehingga keputusan tersebut dapat ketahui bahwa gaya kepemimpinan yang diterapkan oleh STIKes Muhammadiyah Lamongan adalah gaya kepemimpinan demokratis.

Analisis tanggapan responden terhadap setiap pernyataan pada kinerja pegawai

JAS-PT

JURNAL ANALISIS SISTEM PENDIDIKAN TINGGI

ISSN $2580-5339$

eISSN $2620-5718$

Volume 3

Nomor 1

JULI 2019

Hal $21-30$

FORUM DOSEN INDONESIA
Dalam penelitian ini untuk mencari rata-rata dari setiap jawaban responden guna untuk memudahkan menilai dari rata-rata tersebut, maka dapat menggunakan interval untuk menentukan panjang kelas Sudjana (2001:79):

Banyaknya kelas $=5$

$$
p=\frac{5-1}{5} \quad p=0,8
$$


Maka interval dari kriteria penilaian rata-rata dapat diinterpretasikan sebagai berikut:

$\begin{array}{ll}\text { Sangat rendah } & : 1,00-1,79 \\ \text { Rendah } & : 1,80-2,59 \\ \text { Cukup } & : 2,60-3,39 \\ \text { Tinggi } & : 3,40-4,19 \\ \text { Sangat Tinggi } & : 4,20-5,00\end{array}$

Tabel 4 Analisis tanggapan responden mengenai Kinerja pegawai STIKes Muhammadiyah Lamongan

\begin{tabular}{cccccccc}
\hline No & Pernyataan & SS & S & N & TS & STS & Rata-rata \\
\hline 1 & Pernyataan 1 & 9 & 31 & 29 & 5 & 0 & 3,59 \\
2 & Pernyataan 2 & 19 & 52 & 3 & 0 & 0 & 4,21 \\
3 & Pernyataan 3 & 15 & 44 & 14 & 1 & 0 & 3,98 \\
4 & Pernyataan 4 & 5 & 37 & 30 & 2 & 0 & 3,60 \\
5 & Pernyataan 5 & 5 & 35 & 29 & 5 & 0 & 3,54 \\
6 & Pernyataan 6 & 5 & 47 & 21 & 1 & 0 & 3,75 \\
7 & Pernyataan 7 & 11 & 44 & 14 & 5 & 0 & 3,82 \\
8 & Pernyataan 8 & 14 & 42 & 11 & 7 & 0 & 3,85 \\
\hline$\quad$ Total & & & & & & 30,34 \\
& Rata Rata & & & & & & 3,79 \\
\hline
\end{tabular}

Sumber : Data primer diolah

Berdasarkan pada tabel 4, dapat diketahui tanggapan responden mengenai pernyataan kinerja pegawai pada STIKes Muhammadiyah Lamongan dapat dikatakan baik, Hal ini dapat dilihat dari pernyataan pada tabel di atas nilai terendah terdapat pada pernyataan 5 dengan nilai rata-rata 3,54 . Sedangkan nilai tertinggi terdapat pada pernyataan 2 dengan nilai rata-rata yang sama 4,21. Dengan demikian rata-rata keseluruhan dari 8 pernyataan yaitu 3,79 yang berada pada interval $3,40-4,19$, sehingga keputusan tersebut dapat ketahui bahwa kinerja pegawai STIKes Muhammadiyah Lamongan adalah Tinggi.

Hasil Uji Regresi

Tabel 5 Hasiil uji $t$

\begin{tabular}{lrrrrrr}
\hline & \multicolumn{3}{c}{ Unstandardized Coeff. } & \multicolumn{2}{c}{ Standardized Coeff } & \\
Model & $\mathrm{B}$ & Std. Error & Beta & $\mathrm{t}$ & Sig. \\
\hline 1 (Constant) & 19.698 & 2.601 & & 7.574 & .000 \\
Gaya Kepemimpinan & .369 & .089 & & .439 & 4.146 & .000 \\
\hline
\end{tabular}

Sumber : Data primer diolah

Berdasarkan Tabel 5 diatas dengan menggunakan tingkat kepercayaan (confidence interval) $95 \%$ atau $\alpha=0,05$ Hasil pengujian hipotesis menunjukkan bahwa variabel Gaya kepemimpinan memiliki nilai thitung $(4.146)>$ nilai tabel $(1,99)$, maka keputusannya adalah menerima $\mathrm{H}_{\mathrm{a}}$ dan $\mathrm{H}_{0}$ ditolak. Hal ini berarti variabel Gaya Kepemimpinan berpengaruh signifikan terhadap Kinerja Pegawaia di STIKes Muhammadiyah Lamongan

Berdasarkan hasil olah data, variabel gaya kepemimpinan berpengaruh positif dan signifikan terhadap kinerja pegawai yang dibuktikan dengan t hitung $=(4,146)>$ t hitung $(1,99)$. Hal tersebut membuktikan bahwa gaya kepemimpinan mempengaruhi kinerja pegawai STIkes Muhammadiyah Lamongan.

JAS-PT

JURNAL ANALISIS SISTEM PENDIDIKAN TINGG

ISSN $2580-5339$

eISSN $2620-5718$

Volume 3

Nomor 1

JULI 2019

Hal $21-30$

FORUM DOSEN INDONESIA 
Hasil penelitian menunjukkan bahwa gaya kepemimpinan yang diterapkan di STIKes Muhammadiyah Lamongan adalah gaya kepemimpinan demokratis. Dalam uji hipotesis menunjukkan bahwa gaya kepemimpinan berpengaruh positif dan signifikan terhadap kinerja pegawai.

Hal tersebut menjelaskan bahwa semakin demokratis gaya kepemimpinan yang diterapkan maka akan semakin tinggi kinerja pegawai. Gaya kepemimpinan tersebut memiliki perilaku senang menerima saran, pendapat dan kritikan dari bawahan. Gaya kepemimpinan yang perlu dipertahankan terutama pada aspek melibatkan pegawai dalam hal pengambilan keputusan dan perlu meningkatkan aspek di mana pimpinan harus memperhatikan kepentingan pegawai maupun kepentingan rumah sakit. Hasil penelitian ini didukung oleh teori yang dikemukakan oleh Amirullah (2015 : 167),

Hasil survei penelitian ini menunjukkan bahwa kinerja pegawai yang perlu dipertahankan adalah pada aspek di mana setiap pekerjaan yang diberikan kepada pegawai dikerjakan dengan hati-hati. Sedangkan kinerja pegawai yang perlu ditingkatkan adalah pada aspek di mana pegawai harus dapat menyesuaikan diri dengan lingkungan kerja. Hasil survei penelitian ini didukung oleh teori Anwar Prabu (2013 : 67) kinerja pegawai adalah prestasi kerja atau hasil kerja baik kualitas maupun kuantitas yang dicapai SDM persatuan periode waktu dalam melaksanakan tugas kerjanya sesuai dengan tanggung jawab yang diberikan kepadanya. Selain itu hasil penelitian ini didukung oleh teori tentang tahapan manajemen kerja yang dikemukakan oleh Sjafri dan Aida (2007 : 154), tahapan manajemen kerja meliputi beberapa hal sebagai berikut: Pertama, tahapan perencanaan kinerja. Kedua, tahapan pelaksanaan kinerja. Ketiga, tahapan penilaian kinerja. Empat, tahapan perbaikan kinerja.

\section{PENUTUP}

Berdasarkan hasil penelitian dapat diketahui bahwa gaya kepemimpinan berpengaruh positif terhadap kinerja pegawai. Namun ada item pertanyaan yang dijadikan indikator variabel gaya kepemimpinan dan kinerja karyawan memiliki skor rata-rata relatif rendah. Pada variabel gaya kepemimpinan rata-rata terendah terdapat pada item 2 "Tanggapan responden mengenai setiap pegawai diberikan kesempatan untuk menyampaikan ide dan usulan" dengan nilai rata-rata sebesar 3,05 sedangkan pada variabel kinerja karyawan nilai rata-rata terendah terdapat pada item 5 "Tanggapan responden mengenai saya selalu merasa puas dengan hasil kerja saya" dengan nilai rata-rata sebesar 3,54. Oleh karena itu saran yang dapat diberikan kepada pihak STIKes Muhammadiyah Lamongan yaitu pertama, Ketua STIKes Muhammadiyah Lamongan seharusnya terus memberikan kesemeptan untuk menyampaikan ide ide dari seluruh pegawai. Kedua, STIKes Muhammadiyah Lamongan sebaiknya memberikan orientasi kepada pegawai terutama pegawai-pegawai baru, agar pegawai tersebut dapat menyesuaikan diri atau dapat beradaptasi dengan lingkungan kerja di STIKes Muhammadiyah Lamongan.

JAS-PT

JURNAL ANALISIS SISTEM PENDIDIKAN TINGG ISSN $2580-5339$ eISSN $2620-5718$

Volume 3

Nomor 1

JULI 2019

Hal $21-30$

FORUM DOSEN INDONESIA
Dilihat dari hasil penelitian mengenai gaya kepemimpinan dan kinerja pegawai STIkes Muhammadiyah Lamongan terdapat beberapa item pertanyaan yang memiliki nilai ratarata tinggi. Pada variable gaya kepemimpinan nilai rata-rata tertinggi sebesat 4,12 yang terdapat pada item 1 "Tanggapan responden mengenai pimpinan tidak hanya memperhatikan kepentingan perusahaan tetapi juga kepentingan pegawai". Sedangkan pada variable kinerja karyawan nilai rata-rata tertinggi sebesar 4,2 yang terdapat pada item 2 "Tanggapan responden mengenai saya selalu berusaha untuk menyelesaikan 
tugas-tugas yang diberikan perusahaan atau organisasi dengan tepat waktu". Ratarata item yang tinggi ini perlu terus dipertahankan dan ditingkatkan sehingga tujuantujuan STIKes Muhammadiyah Lamongan dapat tercapai.

\section{DAFTAR PUSTAKA}

Amirullah. 2015. Pengantar Manajemen. Jakarta. Penerbit: Mitra Wacana Media. Anwar Prabu Mangkunegara. 2005. Evaluasi Kinerja SDM. Bandung. Penerbit: PT. Refika Aditama.

Erni Tisnawati dan Kurniawan Saefullah. 2014. Pengantar Manajemen. Jakarta. Penerbit : PRENADAMEDIA GROUP.

Ghozali, imam. 2011. Aplikasi Analisis Multi Variat dengan Program SPSS. Semarang: Badan Penerbit di Universitas Diponegoro.

M. Manullang dan Marihot Amh Manullang. 2004. Manajemen Personalia. Yogyakarta. Penerbit : Badjah Mada University Press.

Marwansyah. 2010. Manajemen Sumber Daya Manusia. Bandung. Penerbit : Alfabeta

Sedarmayati dan Syarifudin Hidayat. 2011. Metodologi Penelitian. Bandung. Penerbit : CV. Mandar Jaya.

Sjafri Mangkuprawira dan Aida Vitayala Hubeis. 2007. Manajemen Mutu Sumber Data Manusia. Ciawi Bogar: Penerbit Ghalia Indonesia.

Sugiyono. 2014. Metode Penelitian Manajemen. Bandung. Penerbit: CV Alfabeta.

Sugiyono. 2012. Metode penelitian kuantitatif kualitatif. Bandung. Penerbit: CV Alfabeta.

Sunyoto, Danang. 2011. Metode Penelitian Ekonomi. Yogyakarta. Penerbit: CAPS

Raymond A. Noe, John R. Hollenback, Barry Gerhart dan Patrick M. Wright. 2014. Manajemen Sumber Daya Manusia: Mencapai Keunggulan Bersaing. Jakarta. Salemba Empat.

R. Wayne Mondy. 2008. Manajemen Sumber Daya Manusia. Jakarta. Penerbit : Erlangga 
JAS-PT

JURNAL ANALISIS SISTEM PENDIDIKAN TINGG

ISSN $2580-5339$

eISSN $2620-5718$

Volume 3

Nomor 1

JULI 2019

Hal $21-30$

FORUM DOSEN INDONESIA 